\title{
Biogeochemistry of iron in an acidic lake
}

\author{
Dedicated to Werner Stumm for his $65^{\text {th }}$ birthday
}

Barbara Sulzberger ${ }^{1}$, Jerald L. Schnoor ${ }^{2}$, Rudolf Giovanoli ${ }^{3}$, Janet G. Hering ${ }^{1}$ and Jürg Zobrist ${ }^{1}$

${ }^{1}$ Institute for Water Resources and Water Pollution Control (EAWAG/ETH, CH-8600 Dübendorf, Switzerland

${ }^{2}$ Department of Civil and Environmental Engineering, University of Iowa, Iowa City, USA

${ }^{3}$ Laboratory of Electron Microscopy, Institute of Inorganic Chemistry, University Bern, Switzerland

Key words: Acidic lake; biogeochemistry of iron; diurnal variation; iron(II) oxidation; iron(III) reduction; light induced dissolution; weathering.

\begin{abstract}
In this paper, the fate of iron in Lake Cristallina, an acidic lake in the Alps of Switzerland, is discussed. A simple conceptual model is developed in order to explain the observed diel variation in dissolved iron(II) concentration. Biotite weathering provides reduced iron that is oxidized and subsequently precipitated in the lake. The amorphous $\mathrm{Fe}(\mathrm{III})$ hydroxide $\left(\mathrm{FeOOH} \cdot x \mathrm{H}_{2} \mathrm{O}\right)$, found in the sediments of Lake Cristallina, is an $\mathrm{Fe}(\mathrm{II})$ oxidation product. This oxygenation reaction is most probably catalyzed by bacteria surfaces, as indicated by the relatively high estimated oxidation rate compared to the oxidation rate of the homogeneous oxidation of inorganic Fe(II) species at the ambient $\mathrm{pH}$ of Lake Cristallina ( $\mathrm{pH} 5.4$ at $4^{\circ} \mathrm{C}$ ) and by the scanning electron micrograph pictures. Under the influence of light, these amorphous iron(III)hydroxide phases are reductively dissolved. The net concentration of $\mathrm{Fe}$ (II) reflects the balance of the reductive dissolution and the oxidation/precipitation reactions and tends to parallel the light intensity, leading to a diurnal variation in the $\mathrm{Fe}$ (II) concentration. The rate of the photochemical reductive dissolution of Lake Cristallina iron(III)hydroxides is greatly enhanced in situ and in the laboratory by addition of oxalate to the lake water.
\end{abstract}

\section{Introduction}

Lake Cristallina, Switzerland, is an acidic, oligotrophic lake in the Ticino Alps. Acidic lakes and streams are often found in areas with sensitive geology and hydrology receiving acid deposition. Because of their crystalline rock geology and "flashy" hydrographs, these natural waters have low concentrations of base cations $\left(\mathrm{Ca}^{2+}, \mathrm{Mg}^{2+}, \mathrm{Na}^{+}\right.$and $\left.\mathrm{K}^{+}\right)$and hence low alkalinity. Under the influence of increasing acidic deposition, neutralization by chemical weathering is often insufficient to prevent acidification (acid neutralizing capacities become less than zero). The 
concentrations of dissolved aluminum and iron are elevated in these acid waters as a result of chemical weathering.

Dissolved inorganic aluminum is toxic to fish and other aquatic organisms at concentrations greater than 4-8 $\mu \mathrm{mol}^{-1}$ (Driscoll and Schecher, 1988), and its toxicity to fine roots of trees may be one factor in forest decline (Ulrich, 1984). With varying $\mathrm{pH}$, aluminum is subject to cycles of dissolution and precipitation. Iron undergoes redox reactions in natural waters that are accompanied by dissolution or precipitation (Sulzberger et al., 1989). Dissolution reactions of $\mathrm{Al}(\mathrm{III})$ - and $\mathrm{Fe}(\mathrm{III})$ hydroxides are accompanied by the release of adsorbed compounds into the water column and precipitation reactions are accompanied by the binding of compounds to the surface of the hydrous oxides. Therefore the dissolution/precipitation cycles of aluminum and iron play an important role in the biogeochemical cycling of trace metals and some nutrients (Zinder and Stumm, 1985; White and Driscoll, 1987). Knowledge of the fate of iron and aluminum in acidic waters is a prerequisite to understanding the dynamics of these ecosystems (McKnight and Feder, 1984).

Figure 1 is a schematic representation of the fate of iron and aluminum in a shallow acidic lake where a large fraction of the sunlight reaches the bottom of the lake. Dissolved $\mathrm{Al}(\mathrm{III})$ and $\mathrm{Fe}$ (II) originating from biotite weathering are transported by streams and groundwater to the lake. Some iron(II) is lost via oxidation and precipitation along the way and some dissolved $\mathrm{Al}$ (III) is lost due to precipitation. In the lake, submicron particles of amorphous aluminum(III)hydroxide are ultimately removed from the water column to the sediments. However, aluminum hydroxide may redissolve if the $\mathrm{pH}$ decreases due to snowmelt or rainfall runoff events. Fe(II) transported to the lake is oxidized and subsequently precipitated; biological surfaces may act as templates for these reactions. The transformation of ferrihydrite to goethite is strongly retarded by the presence of silicic acid present as a weathering product (Cornell and Giovanoli, 1987). Under the influence of light, particulate iron may be redissolved. Diurnal variations in the

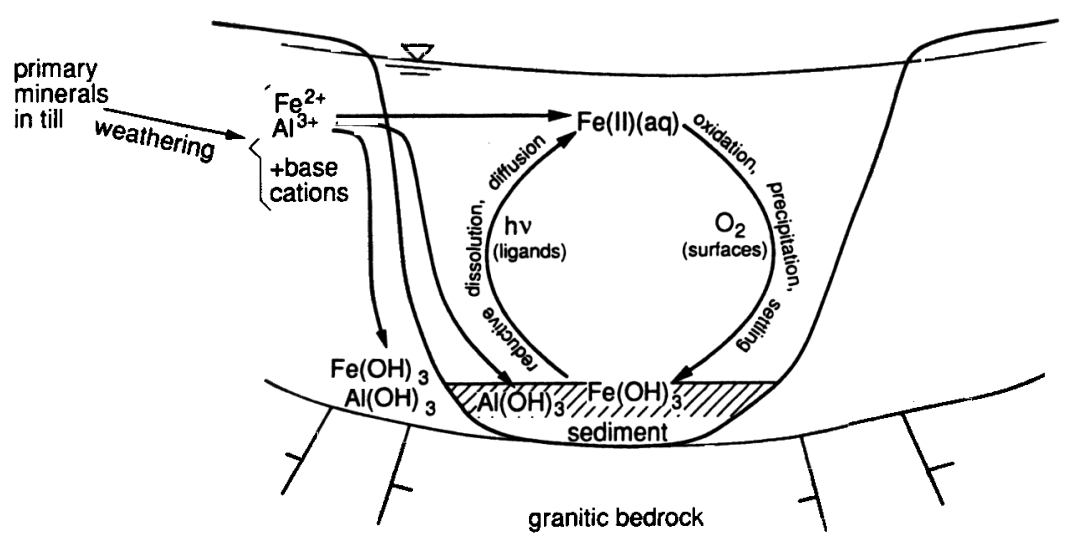

Figure 1. Fate of iron and aluminum in acidic lake water of an alpine catchment area receiving acid deposition 
concentration of dissolved $\mathrm{Fe}$ (II) have been observed in acidic waters (Collienne, 1983; McKnight et al., 1988; McKnight and Bencala, 1988; 1989; McMahon, 1969).

\section{Background}

\section{Kinetics of primary mineral weathering}

The weathering of biotite provides some of the iron(II) and aluminum to drainage waters in the catchment area of Lake Cristallina. As an example of the generation of solutes via chemical weathering of rock-forming minerals, the following chemical equation is provided for biotite dissolution. It is one of the predominant weatherable minerals in the catchment area of Lake Cristallina (Giovanoli et al., 1988):

$$
\begin{aligned}
& \mathrm{KMg}_{(3-x)} \mathrm{Fe}_{(x)} \mathrm{AlSi}_{3} \mathrm{O}_{10}(\mathrm{OH})_{2}(s)+10 \mathrm{H}^{+} \\
& \quad \rightarrow K^{+}+(3-x) \mathrm{Mg}^{2+}+x \mathrm{Fe}^{2+}+\mathrm{Al}^{3+}+3 \mathrm{H}_{4} \mathrm{SiO}_{4}
\end{aligned}
$$

The kinetics of weathering reactions of aluminosilicates and hydrous oxides of aluminum and iron have been studied extensively (Furrer and Stumm, 1986; Stumm et al., 1983; 1987; submitted; Wieland et al., 1988; Zinder et al., 1986). It has been shown that these weathering reactions are surface controlled reactions. In aqueous media, the amphoteric surface hydroxyl groups of hydrous oxides can interact with protons, metal ions and organic or inorganic ligands (Stumm et al., 1980; Schindler and Stumm, 1987). Surface binding of protons or of ligands that form surface chelate complexes or both can promote dissolution of hydrous oxides (Zinder et al., 1986; Stumm et al., 1987). For the proton-promoted dissolution, the following rate law is observed:

$$
R_{H}=k_{H}\left(C_{H}^{s}\right)^{n}
$$

where $C_{H}^{s}$ is the concentration of surface bound protons in $\mathrm{mol} \mathrm{m}^{-2}$ (in excess of that at the point of zero charge) and $k_{H}$ is the rate constant in $h^{-1} \cdot \mathrm{mol}^{-(n-1)} \cdot \mathrm{m}^{2(n-1)}$. The exponent, $n$, corresponds to the oxidation number of the central ion of the oxide, i.e. $n=4,3,2$ for $\mathrm{SiO}_{2}, \delta$ - $\mathrm{Al}_{2} \mathrm{O}_{3}$ and $\mathrm{BeO}$ respectively (Furrer and Stumm, 1986; Schott, in press). Equation 2 is consistent with a generalized rate expression for surface-controlled dissolution reactions involving the mole fraction of dissolution active sites, the surface concentration of sites, and the probability of finding a specific site in the coordinative arrangement of the precursor complex (Wieland et al., 1988; Stumm et al., submitted).

Amorphous aluminum hydroxide present in Lake Cristallina results from precipitation of dissolved $\mathrm{Al}$ (III) originating from aluminosilicate weathering. Submicron precipitates of $\mathrm{Al}(\mathrm{OH})_{3}$ dissolve readily with small decreases in $\mathrm{pH}$ due to the large surface area of these amorphous phases. Aluminum hydroxide dissolution proceeds to saturation; equilibrium expressions assuming control by natural gibbsite can often be employed (Johnson et al., 1981):

$$
\mathrm{Al}(\mathrm{OH})_{3}(s)+3 \mathrm{H}^{+} \rightleftarrows \mathrm{Al}^{3+}+3 \mathrm{H}_{2} \mathrm{O} \quad K=10^{+8.77}
$$


Aluminum toxicity to fish appears to be most severe in waters which are supersaturated with respect to $\mathrm{Al}(\mathrm{OH})_{3}$ (Baker and Schofield, 1982) as is the case in Lake Cristallina (Giovanoli et al., 1988).

\section{Kinetics of iron(II) oxidation}

Iron(II) released by biotite weathering can be transported significant distances at low $\mathrm{pH}$ even under aerobic conditions. Eventually, iron(II) is oxidized to ferrihydrite, $\mathrm{FeOOH} \cdot x \mathrm{H}_{2} \mathrm{O}$, which accumulates in the sediments. Usually, the most important oxidant of $\mathrm{Fe}$ (II) in surface waters is oxygen. Alternative oxidation pathways may involve $\mathrm{H}_{2} \mathrm{O}_{2}$ as an oxidant (Moffett and Zika, 1987) and the photo-oxidation of iron(II) (Braterman et al., 1984; Zuo, 1989). Oxidation by $\mathrm{O}_{2}$ may proceed by several parallel reaction pathways, both homogeneous and heterogeneous. The rate of iron(II) oxygenation depends on the iron speciation and the rate constants for oxidation of the various species. Oxidizable iron species include dissolved inorganic and organic iron(II) complexes and surface-bound iron(II). Adsorption of metal ions, such as $\mathrm{Fe}(\mathrm{II}), \mathrm{Mn}$ (II) and V(IV), on mineral surfaces has been shown to enhance the rate of oxidation (Wehrli, in press). Increased rates of iron(II) oxidation at neutral $\mathrm{pH}$ in the presence of iron(III) hydroxides and autocatalytic oxygenation of ferrous iron have been reported (Tamura et al., 1976; Sung and Morgan, 1980). Bacterial surfaces may also serve as a template for the heterogeneous oxidation of iron(II) and the subsequent reprecipitation of the oxidized product. Recently, McKnight and Bencala (1988) have reported bacterially-mediated iron oxidation in a Colorado mountain stream and have shown that chemoautotrophic iron bacteria can accelerate iron(II) oxidation in natural waters. Complexation by organic ligands may either promote or retard oxidation depending on the relative stabilization of the + III and + II oxidation states. The kinetics of homogeneous iron(II) oxidation in the absence of organic ligands was first studied by Stumm and Lee (1961). At neutral pH, the rate of iron(II) oxidation, $R_{\mathrm{ox}}$, can be expressed as:

$$
R_{\mathrm{ox}}=k\left[\mathrm{Fe}^{2+}\right]\left[\mathrm{OH}^{-}\right]^{2} p_{\mathrm{O}_{2}}
$$

where the rate constant $k$ equals $8 \times 10^{13} \mathrm{~min}^{-1} \mathrm{~atm}^{-1} \mathrm{M}^{-2}$ at $20^{\circ} \mathrm{C}$, and $p_{\mathrm{O}_{2}}$ is the partial pressure of oxygen (approximately $0.2 \mathrm{~atm}$ ) (Stumm and Lee, 1961; Singer and Stumm, 1970).

The overall rate of iron(II) oxidation is the sum of the rates of oxidation of each of the reduced iron species. Thus

$$
R_{\mathrm{ox}}=\sum k_{i}[\mathrm{Fe}(\mathrm{II})]_{i}
$$

where $k_{i}$ is the rate constant for oxidation of the $i^{\text {th }} \mathrm{Fe}(\mathrm{II})$ species. If the concentration of each $\mathrm{Fe}(\mathrm{II})$ species can be expressed as a function of $\left[\mathrm{Fe}^{2+}\right]$ for constant $\mathrm{pH}$ and constant ligand and surface concentrations, then

$$
R_{\mathrm{ox}}=k_{\mathrm{ox}}\left[\mathrm{Fe}^{2+}\right]
$$


where $k_{\mathrm{ox}}$ is a pseudo-first-order rate constant for iron(II) oxidation through all pathways. A minimum rate for the oxidation of iron can be estimated from the rate of homogeneous oxidation of inorganic iron species, based on the values of Stumm and Lee (1961),

$$
R_{\mathrm{ox}}^{\min }=k_{\mathrm{ox}}^{\min }\left[\mathrm{Fe}^{2+}\right]
$$

where $k_{\mathrm{ox}}^{\min }=k\left[\mathrm{OH}^{-}\right]^{2} p_{\mathrm{O}_{2}} \cong 0.2 \cdot 10^{-3} h^{-1}$ at the ambient $\mathrm{pH}$ of Lake Cristallina $\left(\mathrm{pH}=5.4\right.$ at $\left.4^{\circ} \mathrm{C}\right)$.

\section{Kinetics of iron(III) reduction}

In the oxic waters of Lake Cristallina, only photochemical processes are expected to be significant in iron reduction. Under ambient conditions (particularly of $\mathrm{pH}$ ), iron reduction results in an increase in the concentration of dissolved iron.

Photochemical iron reduction can also proceed through several parallel pathways as shown in Fig. 2. Homogeneous photochemical reduction of dissolved iron(III) species, either organic or inorganic complexes, is likely to be negligible due to the low solubility of iron(III)hydroxides and to the low concentration of dissolved organic carbon in Lake Cristallina ( $\cong 0.5 \mathrm{mg} / \mathrm{l})$. In this environment formation of dissolved iron(II) proceeds through light-induced reductive dissolution of iron(III) hydroxides. In organic-free systems, a hydroxylated ferric surface species may be the primary chromophore. In this case, photolysis of the $>\mathrm{Fe}^{\mathrm{III}} \mathrm{OH}$ surface complex by near-UV light would produce dissolved $\mathrm{Fe}$ (II) and the $\mathrm{OH}$-radical (Waite and Morel, 1984) as does photolysis of dissolved $\mathrm{FeOH}^{2+}$ (Faust and Hoigné, in press). In the presence of organic ligands, e.g. anions of dicarboxylic acids, $\mathrm{HL}^{-}$, the surface $\mathrm{OH}$-groups may be replaced by the organic anion. The photochemical reduction of surface iron occurs then either by a ligand-to-metal charge transfer transition of the surface complex, $>\mathrm{Fe}^{\mathrm{III}} \mathrm{L}^{-}$, or by an oxygen-to-iron charge transfer transition of the iron(III)hydroxide (Faust and Hoffmann, 1986; Litter and Blesa, 1988; Siffert, 1989; Siffert et al., in prep.). The reduced iron surface centers may be detached from the surface or else reoxidized by molecular oxygen. Whether the first or the second reaction is predominant depends on the stability of the crystal lattice of the iron(III)hydroxide phase (Siffert et al., in prep.). The light-induced dissolution of iron(III)hydroxides may be autocatalytic due to the catalysis of thermal dissolution by the photochemically formed Fe(II) described by Siffert (1989); Siffert et al. (in prep.), and Cornell and Schindler (1987). This Fe(II) catalyzed dissolution can only occur in the presence of a suitable ligand that can form a ternary surface complex, $>\mathrm{Fe}^{\mathrm{III}} \mathrm{LFe}^{\mathrm{II}+}$, at the surface of the hydrous iron(III) oxide (Suter et al., 1988). Although this pathway is a reductive dissolution, it leads to a gradual increase in the dissolved iron(III) concentration whereas the concentration of dissolved iron(II) is not changed.

The rate of the photochemical reductive dissolution of iron(III)hydroxides is proportional to the concentration of the surface complex, either $>\mathrm{Fe}^{\mathrm{III}} \mathrm{L}^{-}$or $>\mathrm{Fe}^{\mathrm{III}} \mathrm{OH}$ (Siffert et al., in prep.; Waite, 1986; Waite and Morel, 1984). Thus

$$
R_{\mathrm{red}}=\sum k_{j}\{>\mathrm{Fe}(\mathrm{III})\}_{j}
$$




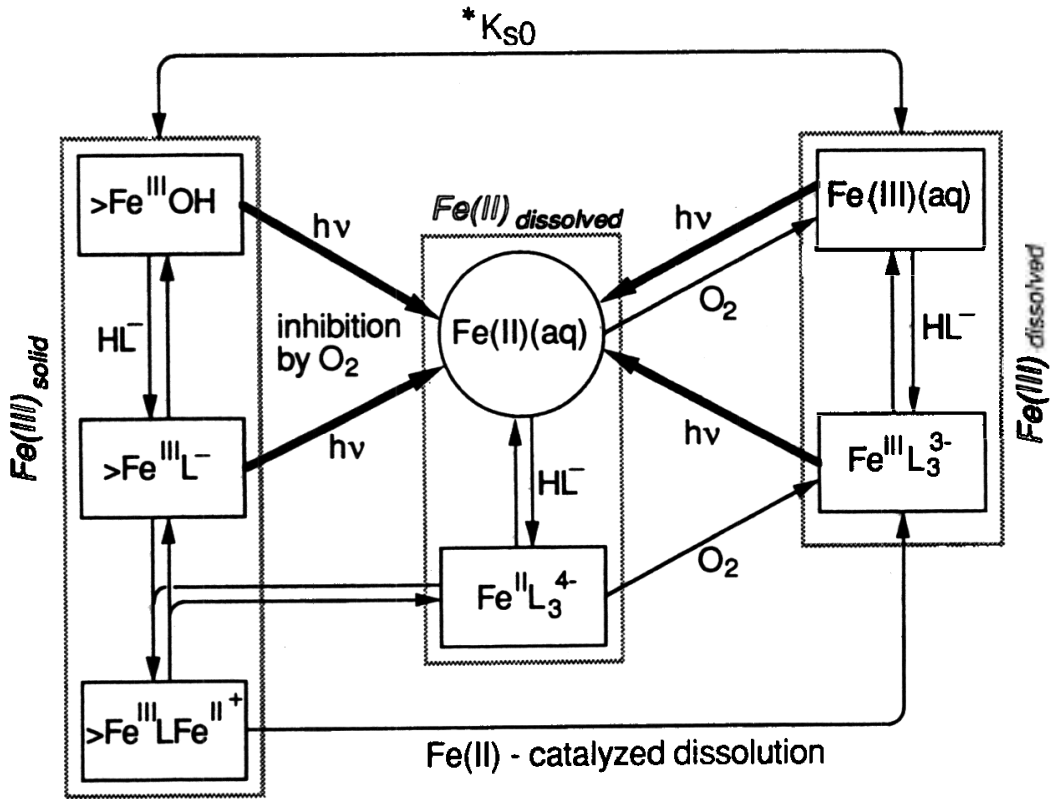

Figure 2. Scheme of the aquatic redox cycles of iron under the influence of light. The boxes on the left hand side of the scheme represent the surface species involved in the redox reactions and the boxes on the right hand side the dissolved $\mathrm{Fe}$ (III) species involved in this redox cycle. Fe(III)(aq) stands for the $\mathrm{Fe}(\mathrm{III})$-complexes with hydroxide ions as ligands, i.e. for $\mathrm{Fe}(\mathrm{OH})^{2+} ; \mathrm{Fe}(\mathrm{OH})_{2}^{+} ; \mathrm{Fe}(\mathrm{OH})_{3}^{0}(\mathrm{aq})$. The most important species in the homogeneous photoreduction of $\mathrm{Fe}$ (III)hydroxide complexes is $\mathrm{Fe}(\mathrm{OH})^{2+}$ (Faust and Hoigné, in press). $\mathrm{HL}^{-}$is the anion of e.g. a dicarboxylic acid. ${ }^{*} \mathrm{~K}_{s 0}$ is the equilibrium constant of the reaction (Stumm and Morgan, 1981):

$$
\mathrm{Fe}(\mathrm{OH})_{3}+3 \mathrm{H}^{+} \not \mathrm{Fe}^{3+}+3 \mathrm{H}_{2} \mathrm{O} \quad{ }^{*} \mathrm{~K}_{s 0}=\frac{\left[\mathrm{Fe}^{3+}\right]}{\left[\mathrm{H}^{+}\right]^{3}}
$$

where the surface concentration of the $j^{\text {th }}$ surface $\mathrm{Fe}$ (III) species is constant for a given $\mathrm{pH}$ and ligand concentration. The rate constant, $k_{j}$, depends on the incident light intensity and on several variables that can be taken to be constant for a given reacting species (such as the wavelengths-integrated extinction coefficients of the chromophore, the quantum efficiency of surface iron(II) formation and the efficiency of detachment of the reduced surface iron from the crystal lattice). For this area of low photosynthetic activity $\mathrm{pH}$ and ligand concentration and therefore the concentration of active species $>\mathrm{Fe}$ (III) $)_{j}$ can be assumed to be constant within the period of the field experiment. The incident light intensity, however, varies diurnally. Thus, the overall reduction rate can be expressed in terms of the incident light intensity and a zero-order rate constant that includes the concentration of the surface species. Then

$$
R_{\text {red }}=k_{\text {red }} \int_{\lambda} I_{0}(\lambda) d \lambda
$$


where $\int_{\lambda} I_{0}(\lambda) d \lambda$ is the incident light intensity of the sunlight at the surface of Lake Cristallina.

The parameters determining the rate constant for the photochemical reductive dissolution of iron(III)hydroxides in well-defined systems have been discussed in detail (Siffert, 1989; Sulzberger, in press). For the present discussion of iron cycling in Lake Cristallina, the above rate expression should be sufficient if the contributing parameters are constant.

\section{A conceptual model}

Simple mathematical models can be constructed to describe the fate and transport of iron in acid lake waters. The accumulation of moles Fe(II) in the lake is equal to the inflow minus the outflow plus or minus the amount due to chemical reactions (oxidation/precipitation and reduction/dissolution):

$$
V\left[d \mathrm{Fe}^{2+}\right] / d \mathrm{t}=Q\left[\mathrm{Fe}^{2+}\right]_{\text {in }}-Q\left[\mathrm{Fe}^{2+}\right]-V k_{\mathrm{ox}}\left[\mathrm{Fe}^{2+}\right]+V k_{\mathrm{red}} \int_{\lambda} I_{0}(\lambda) d \lambda
$$

accumulation inflow outflow oxidation/precipitation reduction/dissolution

where

$V=$ lake volume;

$Q=$ volumetric flowrate;

$\left[\mathrm{Fe}^{2+}\right]_{\text {in }}=$ inflow concentration from seepage/streams;

$k_{\mathrm{ox}}=$ pseudo-first-order rate constant for iron(II) oxidation;

$k_{\text {red }}=$ zero-order rate constant of the photochemical reductive dissolution;

$\int_{1} I_{0}(\lambda) d \lambda=$ light intensity.

During summer months the production and consumption of $\mathrm{Fe}^{2+}$ from the chemical (photochemical and thermal) reactions in the lake exceed the inflows and outflows of $\mathrm{Fe}^{2+}$ within the period of the field experiment so that the first two terms on the right hand side of equation (10) can be neglected. What remains is a simple rate expression that accounts for the photochemical reductive dissolution of the iron(III)hydroxide and the oxidation of dissolved $\mathrm{Fe}(\mathrm{II})$ by oxygen and subsequent precipitation:

$$
\frac{d\left[\mathrm{Fe}^{2+}\right]}{d t}=k_{\mathrm{red}} \int_{\lambda} I_{0}(\lambda) d \lambda-k_{\mathrm{ox}}\left[\mathrm{Fe}^{2+}\right]
$$

At constant light intensity, the steady-state concentration of iron(II) can be calculated:

$$
\left[\mathrm{Fe}^{2+}\right]_{s s}=\frac{k_{\mathrm{red}} \int I_{0}(\lambda) d \lambda}{k_{\mathrm{ox}}}
$$


The dependence of $\left[\mathrm{Fe}^{2+}\right]_{s s}$ on such factors as the concentration of photolytic surface complexes (either $>\mathrm{Fe}^{\mathrm{III}} \mathrm{OH}$ or $>\mathrm{Fe}^{\mathrm{III}} \mathrm{L}^{-}$) and $\mathrm{pH}$ (which are assumed to be constant within the period of the field experiment) is incorporated in the rate constants $k_{\text {red }}$ and $k_{\mathrm{ox}}$. With variations in light intensity, the steady-state approximation is no longer valid. Then the net concentration of dissolved Fe(II) at any time will reflect the balance of reduction and oxidation processes and will tend to parallel the light intensity.

\section{Experimental}

\section{Site description}

Lake Cristallina, at an elevation of $2400 \mathrm{~m}$, in the southern alps of the Maggia valley, Tessin, Switzerland, provides an excellent opportunity to examine chemical weathering and the fate of iron and aluminum in acidic waters. Above the tree-line, most of the watershed consists of very thin soils or exposed bedrock. Cation exchange and vegetation processes are relatively minor compared to forested ecosystems. The bedrock is granitic gneiss with steep slopes and granitic blocks in the upper portion of the catchment area. The lake receives an average of $2.2 \mathrm{~m}$ per year of precipitation, mostly as snow, with an annual runoff of approximately $1.6 \mathrm{~m}$. Figure 3 is a site map of Lake Cristallina in southern Switzerland, showing the location of the lake in the catchment area. Mountains rise steeply in the southwest portion of the 17 ha drainage area. The lake has a surface area of 0.75 ha and a mean hydraulic residence time of 2-4 weeks (Zobrist et al., 1987). The average annual $\mathrm{pH}$ of precipitation is about 4.9, with snow precipitation at about $\mathrm{pH} 5.0$ and rainfall at about $\mathrm{pH} 4.8$ (Mosello and Tartari, 1987). Although dry deposition is not a large contribution to the total acid deposition, there is evidence of some nitrate deposition in the winter snowpack and sulfate deposition in the summer. Lake Cristallina has an average $\mathrm{pH}$ of 5.2, indicating partial neutralization of acid deposition. The primary reactions that serve to neutralize incident acid deposition are chemical weathering and nitrate assimilation/reduction. Principal minerals that contribute solutes to Lake Cristallina via chemical weathering reactions have been identified as plagioclase feldspars (30$45 \%)$, epidote $(2-4 \%)$, biotite $(8-14 \%)$, and orthoclase $(10-14 \%, K$-feldspar) (Giovanoli et al., 1989). Some calcite is believed to enter the catchment area as windblown dust from nearby basins with exposed Triassic dolomite and calcareous shale (Bündnerschiefer).

\section{Materials and methods}

Lake Cristallina was sampled at 1-4h intervals on July 18 and 19 to determine if there was diurnal variation in the concentration of dissolved iron(II). In order to determine the role of organic compounds in the redox cycling of iron in Lake Cristallina, a small enclosure experiment was performed by inserting a Pyrex tube (of $10 \mathrm{~cm}$ diameter) to a depth of approximately $5 \mathrm{~cm}$ into the sediments. The height of 


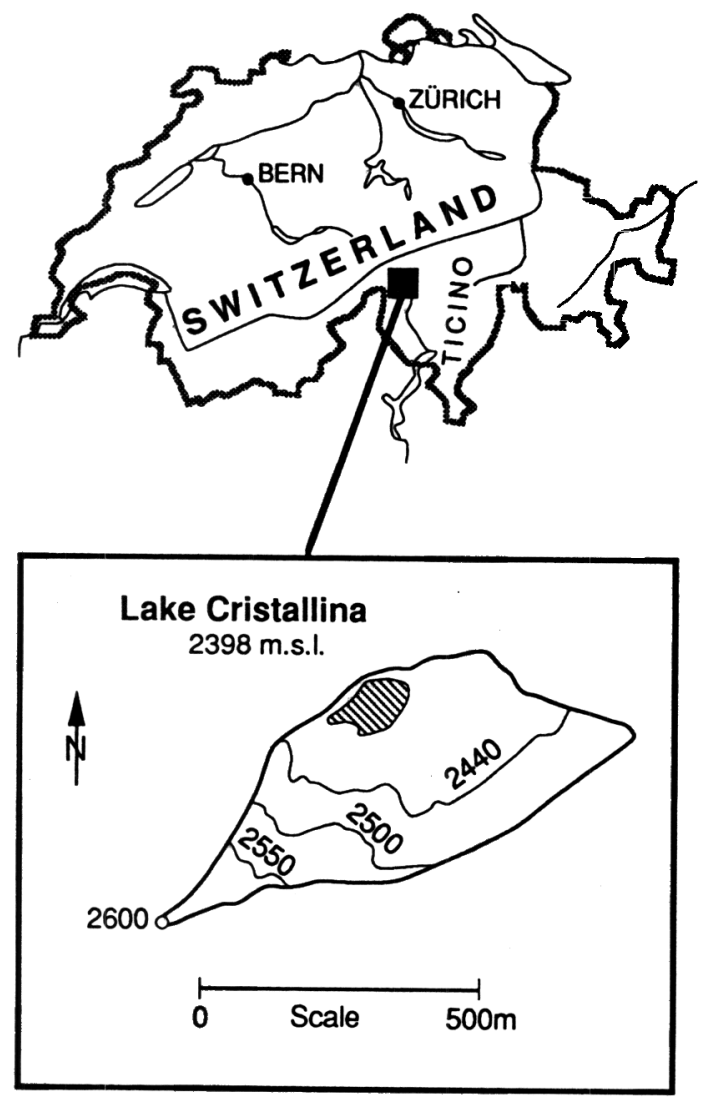

Figure 3. Location map of Lake Cristallina in southern Switzerland. The insert shows the lake and the catchment area with elevation contours

the water column enclosed was approximately $50 \mathrm{~cm}$. Oxalate $\left(\mathrm{C}_{2} \mathrm{Na}_{2} \mathrm{O}_{4}\right.$, p.a. Merck) was added to the lake water within the Pyrex tube to give an oxalate concentration within the Pyrex tube of about $1.5 \mathrm{mM}$. Samples were collected from the tube at the same intervals as the lake samples. The samples for the determination of dissolved iron(II) in Lake Cristallina were filtered in situ through $0.1 \mu \mathrm{m}$ cellulose nitrate filters. $10 \mathrm{ml}$ aliquots were mixed with $1 \mathrm{ml} \mathrm{H}_{2} \mathrm{SO}_{4}, 3.6 \mathrm{M}$, immediately after the filtration to prevent oxidation. The samples were stored cold in plastic tubes until analysis. The $\mathrm{Fe}$ (II) concentration was determined by a standard colorimetric method with ferrozine (Stookey, 1970). Samples were also taken for the determination of total filtrable iron. Iron hydroxide precipitates were readily apparent in certain areas of Lake Cristallina. They could be identified by their orange color and appeared to accumulate in still water and in shallow hollows of superficial sediments of the lake. On July 18 and 19,1989, orange fluffy precipitates were also observed on layers of melting ice that covered about two-thirds of the lake surface. This fluffy precipitate tended to drift away with the current when the ice sheet was moved. The 
precipitate was collected from the ice sheets by suction with a vacuum bottle and hand siphon and transported back to the laboratory for Scanning Electron Microscopy (SEM) and Energy Dispersive X-ray spectroscopy (EDX) and for irradiation experiments. Approximately $1.4 \mathrm{~g}$ of dry material in two liters of lake water was collected in this manner. For $\mathrm{pH}$ measurement of the lake water, the ionic strength was adjusted with $\mathrm{KCl}$. The content of dissolved organic carbon (DOC) was determined using a standard method with the Dohrman DC 80 instrument. The incident light intensity was measured with a LI-185 Quantum/Radiometer/ Photometer, sensitive in the photosynthetic active range of the solar spectrum (400$700 \mathrm{~nm}$ ). Because of the low DOC content of Lake Cristallina, the light intensity, measured $30 \mathrm{~cm}$ below the surface was only about $10 \%$ smaller than the light intensity measured at the surface. The experimental set-up used for the photochemical experiments has already been described elsewere (Siffert, 1989; Siffert et al., in prep.). SEM and EDX analysis were performed with a Hitachi H-600-2 electron microscope and a Tracor $\mathrm{ZN}-5402$ spectrometer. Point analysis was executed in the conventional transmission mode at an enlargement of 10,000. The MSCAN2 program was used for element mapping in the scanning mode.

\section{Results and discussion}

\section{SEM and EDX photomicrographs}

Figure 4 shows a scanning electron micrograph of a corroded feldspar grain and of weathered biotite platelets. Feldspar and biotite crystals are the most weathered minerals found in sediments and in rock fragments. Etch pits were pronounced on the surface of plagioclase grains and occurred in lines following crystal defects as well as randomly across the surface of the grain (Fig. $4 \mathrm{a}$ ). Figure $4 \mathrm{~b}$ shows the breakdown of mica platelets into sheets. The attack occurs at the edges of the biotite grain and propagates through interlayer cleavages. While several investigators have reported gibbsite solubility control in acidic waters, gibbsite could not be identified by X-ray diffraction in Lake Cristallina sediments. Only X-ray amorphous aluminum hydroxide solids were found. Nor was kaolinite, another weathering product, detected. Apparently, temperatures are too cold and water transport too rapid for the formation of kaolinite even in groundwater, where the $\mathrm{pH}$ and $\mathrm{H}_{4} \mathrm{SiO}_{4}$ concentrations are relatively high and the solution is supersaturated with respect to kaolinite. In Fig. 5a scanning electron micrograph and element distribution maps of decomposed biotite platelets in the fine fraction of Lake Cristallina sediment are shown. The Si and Fe maps show high densities of the elements indicating quartz-rich grains and ferric hydroxide precipitates, respectively. In contrast to $\mathrm{Fe}$ and $\mathrm{Si}$, the element map for $\mathrm{Al}$ is mostly uniform over the entire scan, indicating precipitation of tiny particles of amorphous aluminum hydroxide throughout the sediment (Giovanoli et al., 1988). In contrast to aluminum(III)hydroxides that sorb throughout the sediments as submicron point flocs, the iron(III) hydroxides coagulate in flakes of a few $\mathrm{mm}$ in the largest dimension and form patches of clearly visible orange superficial sediments or accumulate on floating ice sheets. Figure 6 shows an EDX analysis of 

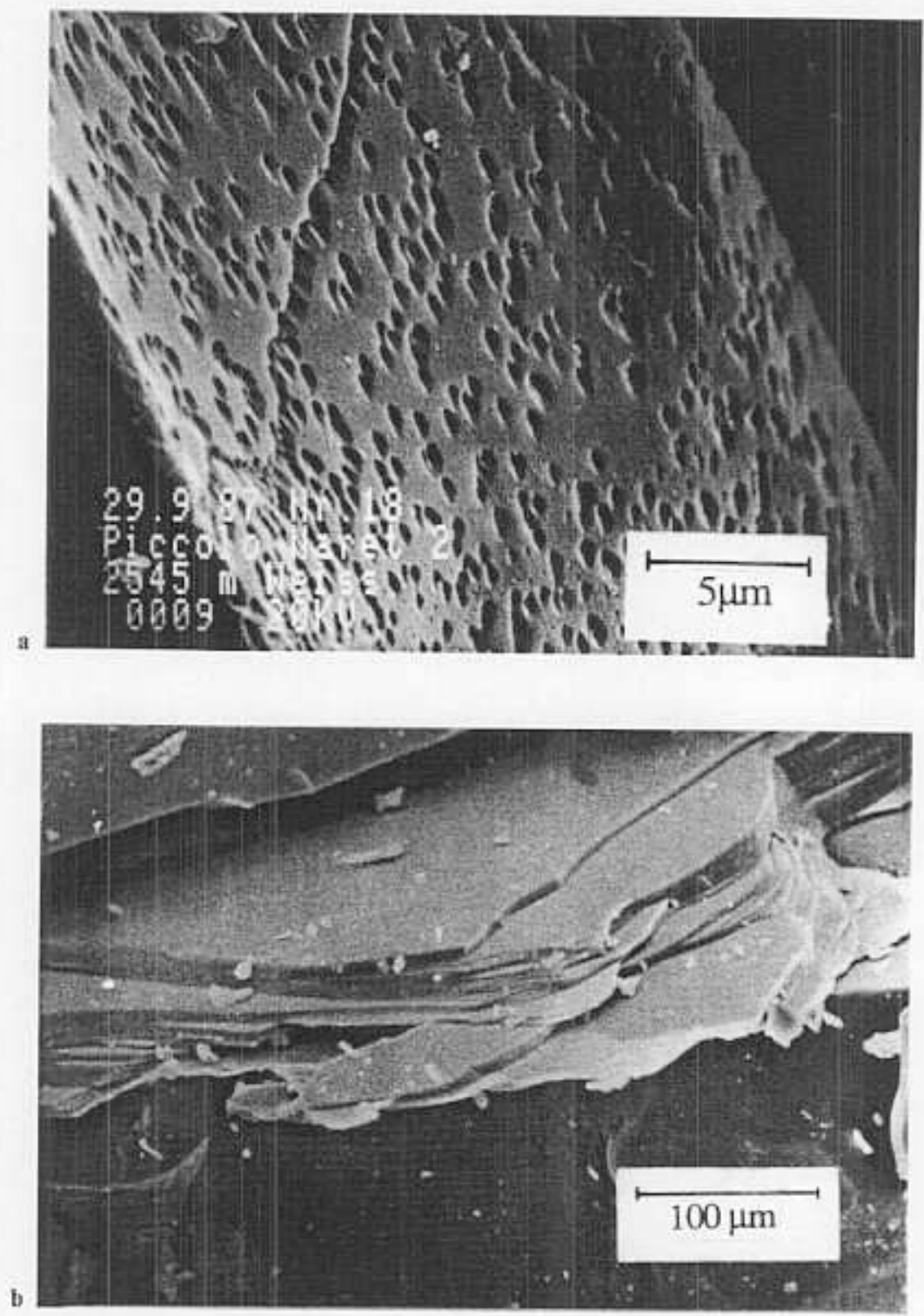

Figure 4. a) Scanning electron micrograph of a corroded feldspar grain. The picture shows the etch pits, which are randomly distributed throughout the grain and also follow crystal defects indicating surface controlled dissolution. b) Scanning electron micrograph of a pack of biotite platelets. The pack is most weathered at the edges of the platelets 


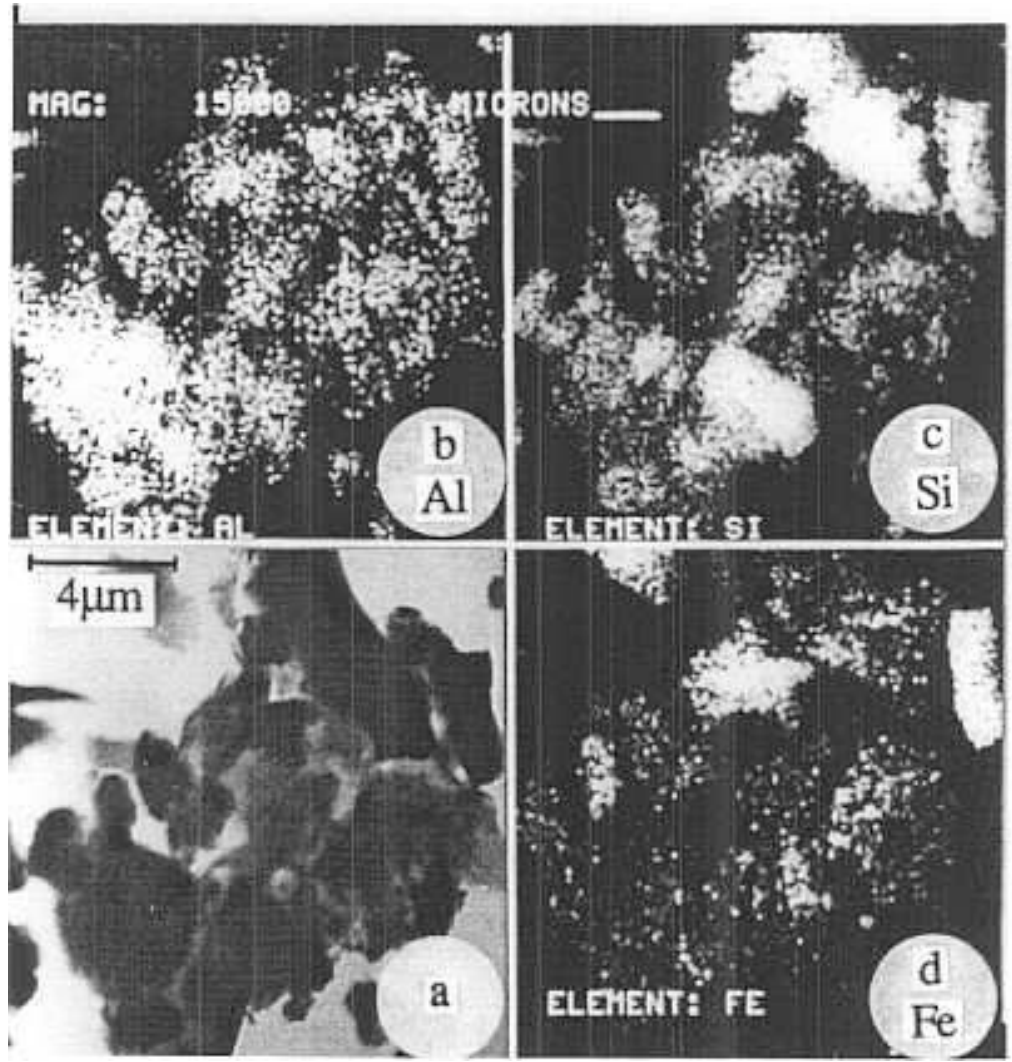

Figure 5. a) Scanning electron micrograph of decomposed biotite platelets in the fine fraction of Lake Cristallina sediments. b)-d) Element distribution maps of $\mathrm{Al}, \mathrm{Si}$ and $\mathrm{Fe}$ respectively

ferric hydroxide precipitate that was collected from the ice sheets in Lake Cristallina. These were $\mathrm{X}$-ray amorphous, i.e. ferrihydrite, $\mathrm{FeOOH} \cdot x \mathrm{H}_{2} \mathrm{O}$, and fairly pure as can be seen from the EDX spectrum. The SEM picture, shown in Fig. 7, indicates that this amorphous iron(III)hydroxide phase is associated with bacteria filaments. It would seem that bacteria are either utilizing the reduced $\mathrm{Fe}(\mathrm{II})$ as an energy source (chemoautotrophic bacteria) or else they are serving as a surface template for the oxidation of $\mathrm{Fe}$ (II) and subsequent precipitation. It is not possible to differentiate the type of bacteria with SEM; this is the subject of future research. In either case, the role of bacteria as a catalyst in the oxygenation of $\mathrm{Fe}$ (II) and subsequent precipitation must be considered.

\section{Redox cycle of iron in Lake Cristallina}

The overall mass balance for primary weathering in the catchment area of Lake Cristallina, based on chemical analyses of the dissolved species in the lake water and 


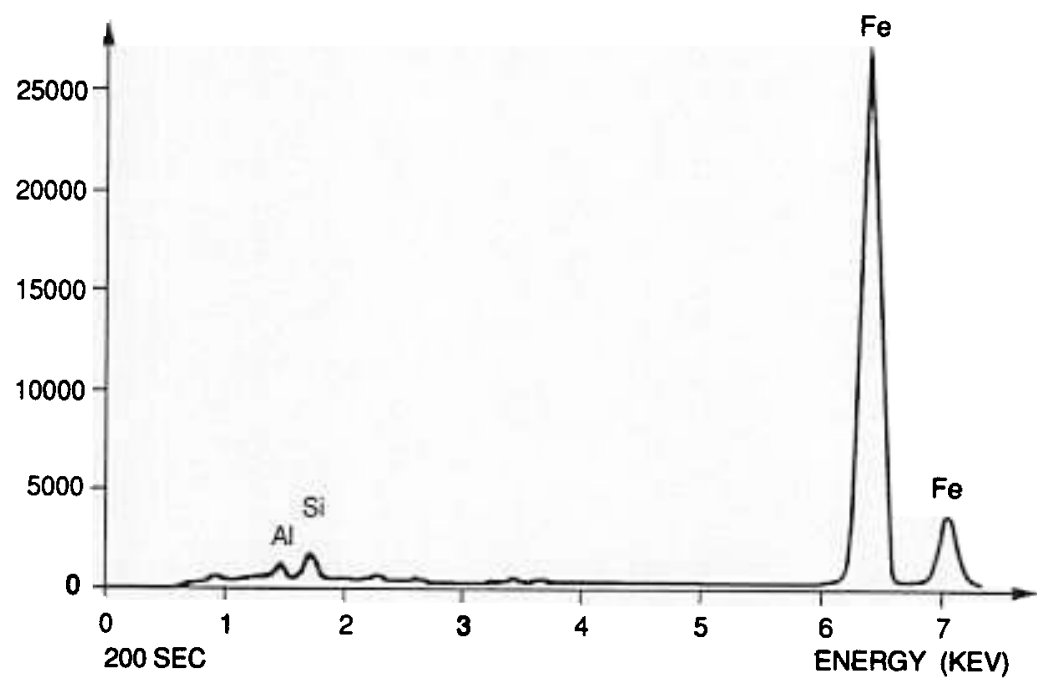

Figure 6. Energy-disperse X-ray spectrum of precipitates collected from melting ice-sheets in Lake Cristallina

taking into account the atmospheric input (Giovanoli et al., 1988, is as follows:

$$
\begin{gathered}
\mathrm{Ca}_{6} \mathrm{Mg}_{0.5} \mathrm{Na}_{3} \mathrm{~K}_{2} \mathrm{Fe}_{2.5} \mathrm{Al}_{12} \mathrm{Si}_{25} \mathrm{O}_{79.5}+18 \mathrm{H}^{+}+\frac{123}{2} \mathrm{H}_{2} \mathrm{O} \rightarrow 3 \mathrm{Na}^{+}+2 \mathrm{~K}^{+} \\
+6 \mathrm{Ca}^{2+}+\frac{1}{2} \mathrm{Mg}^{2+}+25 \mathrm{H}_{4} \mathrm{SiO}_{4}+12 \mathrm{Al}(\mathrm{OH})_{3}(s)+2.5 \mathrm{Fe}(\mathrm{OH})_{2}
\end{gathered}
$$

Every liter of water passing through Lake Cristallina dissolves one micromole of the hypothetical "aluminosilicate" composition. Acidic deposition is thereby neutralized and base cations are released as well as silicic acid, amorphous aluminumhydroxide and dissolved iron(II). About half of the $\mathrm{Al}(\mathrm{OH})_{3}$ is redissolved and appears as inorganic aluminum in discharge waters. On a mass basis $\left(\mathrm{kg} \cdot \mathrm{ha}^{-1} \cdot \mathrm{y}^{-1}\right)$, the overall reaction can also be written:

$$
\begin{gathered}
34 \text { "aluminosilicates" }+0.22 \mathrm{H}^{+}+13 \mathrm{H}_{2} \mathrm{O} \rightarrow 0.8 \mathrm{Na}^{+}+0.9 \mathrm{~K}^{+}+2.9 \mathrm{Ca}^{2+} \\
+0.14 \mathrm{Mg}^{2+}+29 \mathrm{H}_{4} \mathrm{SiO}_{4}+11 \mathrm{Al}(\mathrm{OH})_{3}+2.7 \mathrm{Fe}(\mathrm{OH})_{2}
\end{gathered}
$$

The numbers in this equation have the unit $\left[\mathrm{kg} \cdot \mathrm{ha}^{-1} \cdot \mathrm{y}^{-1}\right]$. The hydrogen ion deposition amounts to $224 \mathrm{eq} \cdot \mathrm{ha}^{-1} \cdot \mathrm{y}^{-1}$ which is a threshold for acidification of the most sensitive lakes in northern temperate climates (Schnoor and Stumm, 1986). Of the $2.7 \mathrm{~kg} \cdot \mathrm{ha}^{-1} \cdot \mathrm{y}^{-1}$ of $\mathrm{Fe}(\mathrm{OH})_{2}$ that is released from weathering reactions, virtually all of it is oxidized and remains in the catchment area, accounting for the formation of $3.2 \mathrm{~kg} \cdot \mathrm{ha}^{-1} \cdot \mathrm{y}^{-1}$ of solid ferric hydroxide in the soils and sediments.

Under the influence of light the solid iron(III) phase is reductively dissolved and the dissolved $\mathrm{Fe}$ (II) is eventually reoxidized and subsequently reprecipitated. Since the rate of the photochemical reductive dissolution depends on the light intensity, this 


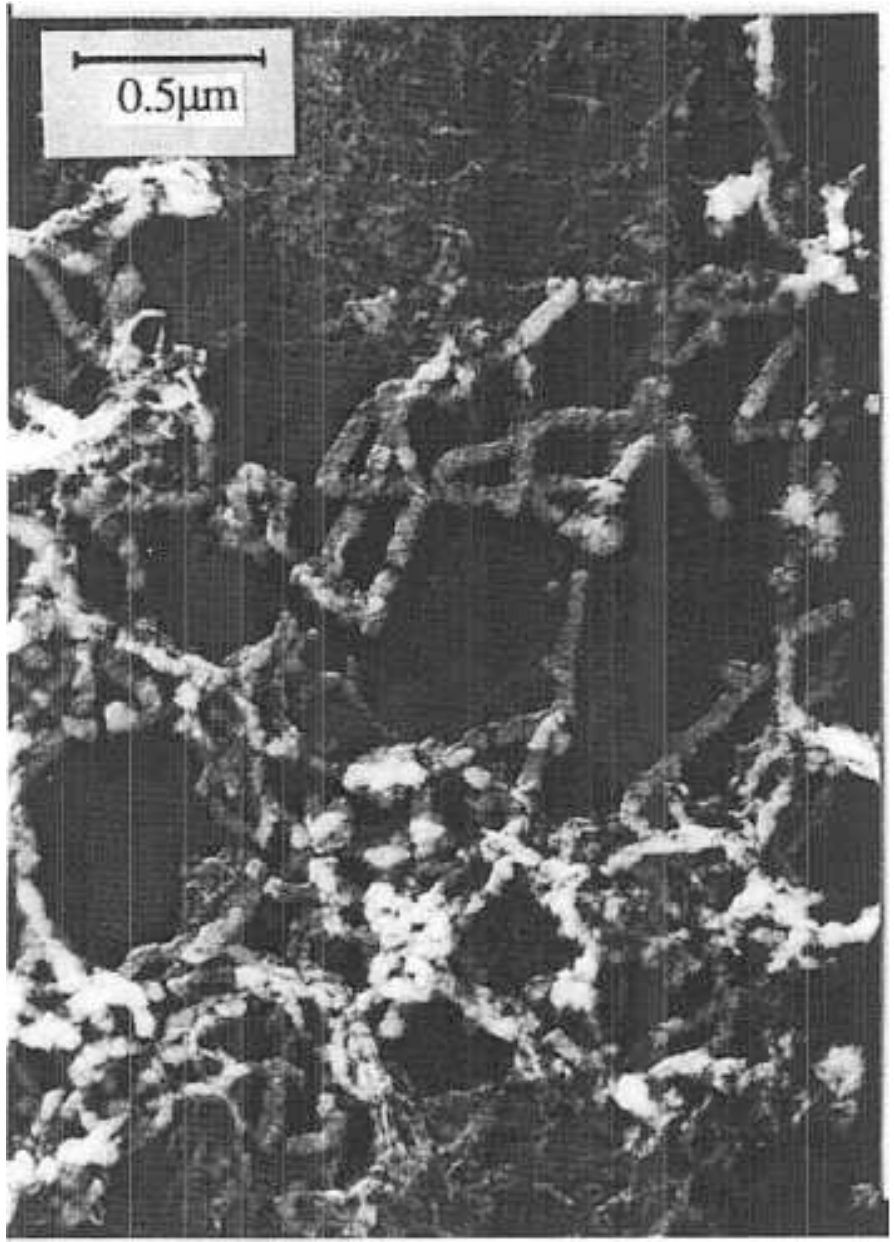

Figure 7. Scanning electron micrograph of the iron-rich precipitates collected from melting icesheets in Lake Cristallina. The white areas are X-ray amorphous iron(III)hydroxide associated with particles resembling bacteria

redox cycle of iron results in a diurnal variation of the concentration of dissolved iron(II). Figure 8 shows the diurnal variation of the Fe(II) concentration in Lake Cristallina over a 26-h sampling period. On July 18, a maximum in the concentration of dissolved iron(II) was observed shortly after noon. Under overcast conditions the incident light intensity in the early afternoon dropped to about $30 \%$ of the noon-time value and the concentration of iron(II) decreased rapidly due to oxidation of $\mathrm{Fe}$ (II). During the night, $\mathrm{Fe}$ (II) was further oxidized. The earliest July 19 sample was only taken about two hours after sunrise. The incident light intensity increased during the morning of July 19 and reached a maximum at noon, which was paralleled by the increase in the $\mathrm{Fe}$ (II) concentration. From these data one can tentatively make a 


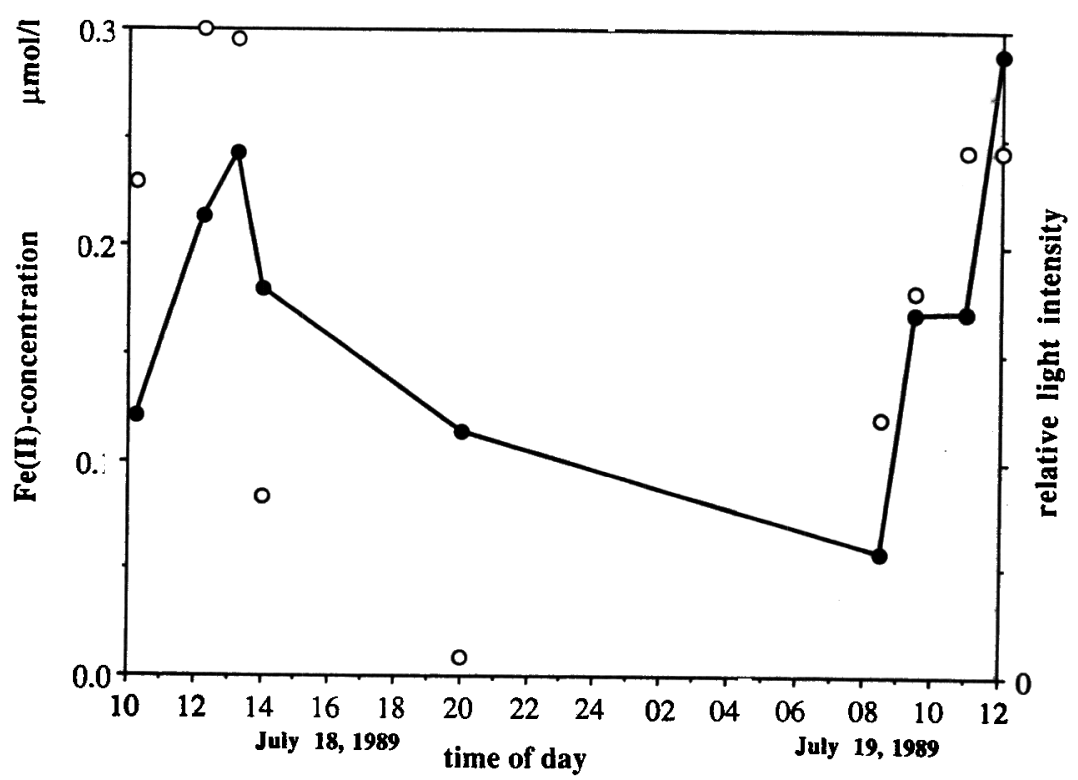

Figure 8. Diurnal variation of the concentration of dissolved $\mathrm{Fe}(\mathrm{II}) \bullet$ and of the incident light intensity $O$ in Lake Cristallina. (The maximal measured light intensity is arbitrary set to one)

crude estimation of the rate constant of $\mathrm{Fe}$ (II) oxidation, based on the decrease in $\mathrm{Fe}$ (II) concentration between 8 p.m. on July 18 and $8.30 \mathrm{a} . \mathrm{m}$. on July 19. This provides a conservative estimate since photochemical reductive dissolution from dawn to 8.30 a.m. on July 19 is neglected. For an (assumed) pseudo-first-order dependence of oxidation rate on $\left[\mathrm{Fe}^{2+}\right]$, that is

$$
\frac{d\left[\mathrm{Fe}^{2+}\right]}{d t}=-k_{\mathrm{ox}}\left[\mathrm{Fe}^{2+}\right]
$$

the rate constant $k_{\text {ox }}$ can be calculated by integrating equation (15). For the $\mathrm{Fe}$ (II) concentrations measured at 8 p.m. on July 18 and 8.30 a.m. on July 19 the value obtained for this pseudo-first-order rate constant of oxidation, $k_{\mathrm{ox}}$, is $56 \cdot 10^{-3} \mathrm{~h}^{-1}$. This value can be compared with the estimated minimum rate constant based on homogeneous oxidation of inorganic $\mathrm{Fe}$ (II) species $\left(k_{\mathrm{ox}}^{\min }=0.2 \cdot 10^{-3} \mathrm{~h}^{-1}\right.$ at the ambient $\mathrm{pH}$ of Lake Cristallina at $4^{\circ} \mathrm{C}$, see equation (7)). The higher in situ rate constant for oxidation suggests that the oxidation of $\mathrm{Fe}$ (II) by oxygen in Lake Cristallina is catalyzed by bacteria surfaces. This hypothesis is supported by the scanning electron micrograph pictures, which indicate that the iron(III)hydroxide is associated with bacteria and is consistent with recent observations of bacteriallymediated iron oxidation in acidic streams (McKnight and Bencala, 1988).

The potential significance of organic reductants was examined in an enclosure experiment. A Pyrex glass tube was inserted into the iron-rich sediment and oxalic acid was added to the enclosed lake water to give a final concentration of $1.5 \mathrm{mM}$. 


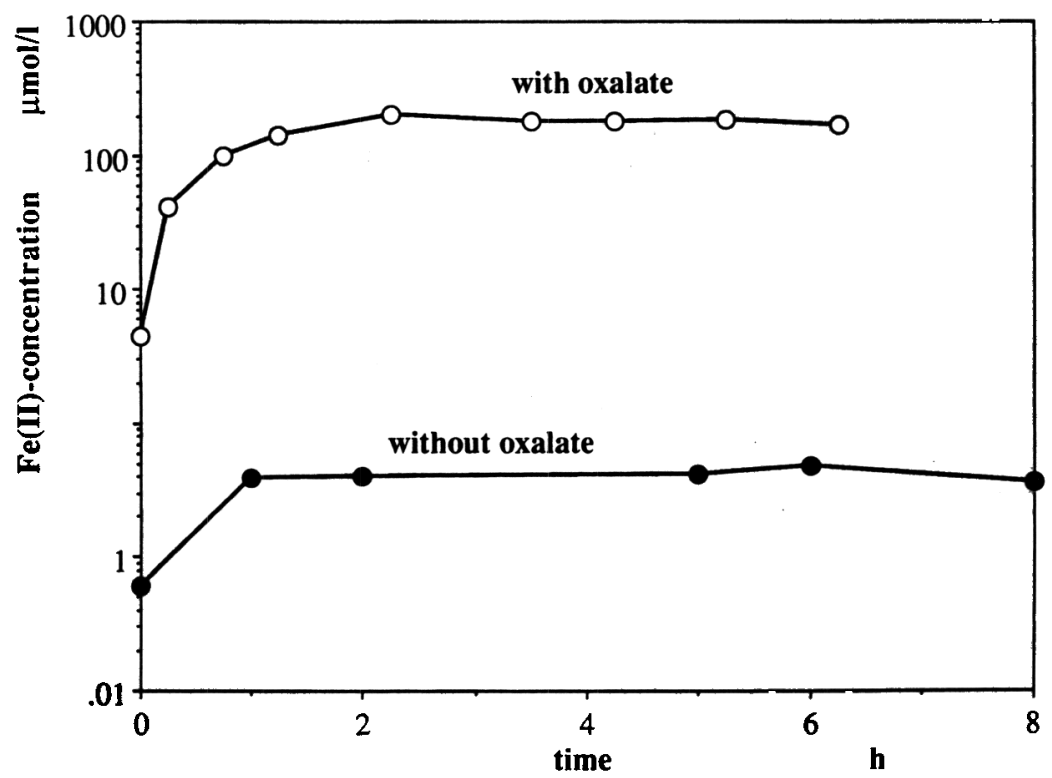

Figure 9. Steady state concentration of dissolved iron(II) in the presence and in the absence of oxalate under the influence of light. Experimental conditions: $300 \mathrm{ml}$ suspension of iron-rich sediment collected from ice-sheets in Lake Cristallina $\left(0.7 \mathrm{gl}^{-1}\right)$. Initial oxalate concentration: $1 \mathrm{mM}$. White light from a Xenon high pressure lamp filtered with a pyrex filter; incident light intensity, $I_{0} \cong 1 \mathrm{~kW} \mathrm{~m}^{-2}$. The suspension was open to the atmosphere and stirred throughout the experiment

The concentrations of dissolved iron(II) in the presence of oxalate were approximately ten times the concentrations sampled outside the enclosure. Figure 9 shows two preliminary laboratory experiments carried out with suspensions of ferrihydrite collected from floating ice sheets in Lake Cristallina. Both experiments were performed under atmospheric oxygen. In one experiment oxalate was added to the suspension. Steady-state concentrations of dissolved iron(II) were obtained after one hour without oxalate and after 3.5 hours with $1 \mathrm{mM}$ oxalate. The steady-state concentration in the presence of oxalate was about 400 times higher than without oxalate. These laboratory experiments with ferrihydrites from Lake Cristallina confirm the observations made in the field with the enclosure experiment. It has been shown that oxalate is a very efficient ligand in the light-induced dissolution of iron(III)hydroxides (Cornell and Schindler, 1987; Siffert, 1989; Siffert et al., in prep.). Oxalate can form inner-sphere complexes at the surface of hydrous $\mathrm{Fe}$ (III) oxides. In the presence of light it acts as an efficient electron donor, since, once oxidized, the oxalate radical undergoes a fast decarboxylation reaction yielding $\mathrm{CO}_{2}$ and the $\mathrm{CO}_{2}^{-}$radical which can reduce a second surface iron(III) in a thermal reaction. Furthermore, since the efficiency of detachment of reduced surface iron from the crystal lattice depends not only on the crystallinity of the solid phase but also on the coordinative environment of the reduced iron centers, oxalate also enhances the rate of detachment (Banwart, 1989). Whether or not surface hydroxyl groups play 
a role in the photochemical dissolution of iron(III)hydroxides, in Lake Cristallina, as has been proposed for the iron photoreduction in an acidic mountain stream (McKnight et al., 1988), will be subject of future investigations.

\section{Conclusions}

The diurnal variation in the concentration of dissolved iron(II) in Lake Cristallina is interpreted in terms of photochemical reductive dissolution of the amorphous iron(III)hydroxide phase and oxidation of iron(II) and subsequent precipitation. The relatively high rate constant of iron(II) oxidation compared to the rate constant of the homogeneous oxidation of $\mathrm{Fe}$ (II) under natural water conditions suggests that oxidation of iron(II) in Lake Cristallina is catalyzed by surfaces, most probably bacterial surfaces. This hypothesis is supported by the scanning electron micrograph pictures, which indicate that the iron(III)hydroxide is associated with bacteria. Oxalate addition results in significantly elevated concentrations of $\mathrm{Fe}(\mathrm{II})$. This experimental observation demonstrates the importance of the concentration and type of naturally occurring ligands in the photochemical reductive dissolution of iron(III)hydroxides in natural waters, since the rate of this heterogeneous photoredox reaction depends on the surface concentration of the absorbed reductant and the rate constant on whether a reductant forms an inner- or an outer-sphere, a monodentate or a bidentate surface complex at the surface of an iron(III)hydroxide.

The weatherable minerals, feldspars and biotite, in the catchment area of Lake Cristallina have been elucidated by electron microscopy. The feldspar minerals provide calcium, sodium and potassium ions to the lake. Minor amounts of epidote (a hydrous silicate, $\left.\mathrm{Ca}_{2}(\mathrm{Al}, \mathrm{Fe})_{3}\left(\mathrm{SiO}_{4}\right)_{3} \mathrm{OH}\right)$ and trace quantities of wind-blown calcareous dust may also supply calcium to the water. Biotite provides a source of magnesium, potassium and reduced iron to groundwater and lakewater. Ferrous iron from biotite weathering is eventually oxidized, resulting in formation of amorphous ferric hydroxide, detectable as flakes in the sediments and as coatings on some mineral grains. Aluminum ions from aluminosilicate weathering reactions precipitate as submicron amorphous aluminum hydroxide, and these small particles are observed throughout the sediments. They are subject to rapid re-dissolution and precipitation depending on changes in $\mathrm{pH}$ of these acidic waters.

\section{ACKNOWLEDGEMENTS}

We are deeply indebted to the intellectual leadership and support of Werner Stumm, who has introduced aquatic chemistry to the vernacular of environmental science, a true pioneer in our field. His original papers from 1961 and 1970, cited herein, stimulated this research. It is to Werner Stumm that this article is dedicated. The background of the photochemical reductive dissolution of iron(III)(hydr)oxides is mainly based on work done by Christophe Siffert in his Ph.D. thesis. We benefitted from discussions with Steven Banwart, Daniel Suter, Laura Sigg, François Morel and James Morgan regarding iron chemistry in natural waters. We thank Jürg Hoigné for reviewing this article. Research was supported by the Swiss National Science Foundation (NFP 14) and by the U.S. EPA Watershed Manipulation Project. This article has not been "peer and policy" reviewed by the Agency, and no official endorsement should be inferred. 


\section{REFERENCES}

Baker, J. P., C. L. Schofield, 1982, Aluminum toxicity to fish in acidic waters. Water Air Soil Pollut. 18:289-309.

Braterman, P. S., A. G. Cairns-Smith, R. W. Sloper, 1984, Photo-oxidation of iron(II) in water between $\mathrm{pH} 7.5$ and 4.0. J. Chem. Soc. Dalton Trans.: 1441-1445.

Collienne, R. H., 1983, Photoreduction of iron in the epilimnion of acidic lakes. Limnol. Oceanogr. 28:83-100.

Cornell, R. M., R. Giovanoli, 1987, The influence of silicate species on the morphology of goethite ( $\alpha$ $\mathrm{FeOOH}$ ) grown from ferrihydrite. Chem. Comm., J. Chem. Soc., London: 413.

Cornell, R. M., P.W. Schindler, 1987, Photochemical dissolution of goethite in acid/oxalate solution. Clays and Clay Minerals 35:347-352.

Driscoll, C. T., W. D. Schecher, 1988, Aluminum in the environment. In: H. Sigel and A. Sigel (eds.), Metal Ions in Biological Systems, Marcel Dekker, Inc., New York.

Faust, B. C., M. R. Hoffmann, 1986, Photoinduced reductive dissolution of $\alpha-\mathrm{Fe}_{2} \mathrm{O}_{3}$ by bisulfite. Environ. Sci. Technol. 20:943-948.

Faust, B. C., J. Hoigné, Photolysis of Fe(III)-hydroxy complexes as sources of OH radicals in clouds, fog and rain. Atmospheric Environment, in press.

Furrer, B., W. Stumm, 1986, The coordination chemistry of weathering: I. Dissolution kinetics of $\delta$ $\mathrm{Al}_{2} \mathrm{O}_{3}$ and BeO. Geochim. Cosmochim Acta 50:1847-1860.

Giovanoli, G., J. L. Schnoor, L. Sigg, W. Stumm, J. Zobrist, 1988, Chemical weathering of crystalline rocks in the catchment area of acidic Ticino lakes, Switzerland. Clays and Clay Minerals 36:521 529.

Johnson, N. M., C. T. Driscoll, J. S. Eaton, G. E. Likens, W. H. McDowell, 1981, "Acid rain", dissolved aluminum and chemical weathering at the Hubbard Brook Experimental Forest, New Hampshire. Geochim. Cosmochim. Acta 45:1421-1437.

Litter, M. I., M. A. Blesa, 1988, Photodissolution of iron oxides I. Maghemite in EDTA solutions. J. Colloid Interface Sci. 125:679-687.

McKnight, D. M., K. E. Bencala, 1988, Diel variations in iron chemistry in an acidic stream in the Colorado Rocky Mountains. Arctic and Alpine Research 20:492-500.

McKnight, D. M., K. E. Bencala, 1989, Reactive iron transport in an acidic mountain stream in Summit County, Colorado: A hydrologic perspective. Geochim. Cosmochim. Acta 53:22252234.

McKnight, D. M., G. L. Feder, 1984, The ecological effect of acid conditions and precipitation of hydrous metal oxides in a Rocky Mountain stream. Hydrobiol. 119:129-138.

McKnight, D. M., B. A. Kimball, K. E. Bencala, 1988, Iron photoreduction and oxidation in an acidic mountain stream. Science 240:637-640.

McMahon, J.W., 1969, The annual and diurnal variation in the vertical distribution of acid-soluble ferrous and total iron in a small dimictic lake. Limnol. Oceanogr. 14:357-362.

Moffett, J. W., R. G. Zika, 1987, Reaction kinetics of hydrogen peroxide with copper and iron in seawater. Environ. Sci. Technol. 21:804-810.

Mosello, R., G. Tartari, 1987, Effect of acid precipitation on subalpine lakes. Water Quality Bull.: 96-100.

Schindler, P. W., W. Stumm, 1987, The surface chemistry of oxides, hydroxides and oxide minerals. In: W. Stumm (ed.), Aquatic Surface Chemistry, Wiley-Interscience, New York.

Schnoor, J., W. Stumm, 1986, The role of chemical weathering in the neutralization of acidic deposition, Schweiz. Z. Hydrol. 48:171-195.

Schott, J., Modelling of the dissolution of strained and unstrained multiple oxides: The surface speciation approach. In: W. Stumm (ed.), Aquatic Chemical Kinetics - Reaction Rates of Processes in Natural Waters, Wiley-Interscience, New York, in press.

Siffert, C., 1989, L'effet de la lumière sur la dissolution des oxydes de fer(III) dans les milieux aqueux. Ph.D. Thesis, ETH (Fed. Inst. Technol.) Zurich, No. 8852.

Siffert, C., B. Sulzberger, W. Stumm, in preparation.

Singer, P. C., W. Stumm, 1970, Acidic mine drainage: the rate-determining step. Science 167:11211123. 
Stookey, L. L., 1970, Ferrozine - a new spectrophotometric reagent for iron, Anal. Chem. 42:779_ 781.

Stumm, W., G. Furrer, B. Kunz, 1983, The role of surface coordination in precipitation and dissolution of mineral phases. Croat. Chem. Acta 56:593-611.

Stumm, W., R. Kummert, L. Sigg, 1980, A ligand exchange for the adsorption of inorganic and organic ligands at hydrous oxide interfaces. Croat. Chem. Acta 53:291-312.

Stumm, W., G. F. Lee, 1961, Oxygenation of ferrous iron. Industrial and Engineering Chem. $53: 143-146$.

Stumm, W., J.J. Morgan, 1981, Aquatic Chemistry: An Introduction Emphasizing Chemical Equilibria in Natural Waters, Wiley-Interscience, New York.

Stumm, W., B. Sulzberger, J. Sinniger, The coordination chemistry of the oxide-electrolyte interface; the dependence of surface reactivity (nucleation, dissolution, redox reactions) on surface structure. Croat. Chem. Acta, submitted.

Stumm, W., B. Wehrli, E. Wieland, 1987, Surface complexation and its impact on geochemical kinetics. Croat. Chem Acta 60:429-456.

Suter, D., C. Siffert, B. Sulzberger, W. Stumm, 1988, Catalytic dissolution of iron(III)(hydr)oxides by oxalic acid in the presence of Fe(II). Naturwissenschaften 75:571-573.

Sulzberger, B., Photoredox reactions at hydrous metal oxide surfaces; a surface coordination chemistry approach. In: W. Stumm (ed.), Aquatic Chemical Kinetics - Reaction Rates of Processes in Natural Waters, Wiley-Interscience, New York, in press.

Sulzberger, B., D. Suter, C. Siffert, S. Banwart, W. Stumm, 1989, Dissolution of Fe(III)(hydr)oxides in natural waters; laboratory assessment on the kinetics controlled by surface coordination. Marine Chemistry 28:1-19.

Sung, W., J. J. Morgan, 1980, Kinetics and product of ferrous iron oxygenation in aqueous systems. Environ. Sci. Technol. 14:561-567.

Tamura, H., K. Goto, M. Nagayama, 1976, The effect of ferric hydroxide on the oxygenation of ferrous ions in neutral solutions. Corros. Sci. 16:197-207.

Ulrich, B., 1984, Interaction of indirect and direct effects of air pollutants in forests. In: C. Troyanowsky (ed.), Air Pollution and Plants, Deerfield Beach, Florida.

Waite, T. D., 1986, Photoredox chemistry of colloidal metal oxides. In: J. A. Davis and K. F. Hayes (eds.), Geochemical Processes at Mineral Surfaces, Washington, ACS Symp. Ser. no. 323.

Waite, T. D., F. M. M. Morel, 1984, Photoreductive dissolution of colloidal iron oxide: effect of citrate. J. Colloid Interface Sci. 102:121-137.

Wehrli, B., Redox reactions of metal ions at mineral surfaces. In: W. Stumm (ed.), Aquatic Chemical Kinetics - Reaction Rates of Processes in Natural Waters, Wiley-Interscience, New York, in press.

White, J. R., C. T. Driscoll, 1987, Zinc cycling in an acidic Adirondack Lake. Environ. Sci. Technol. 21:211-216.

Wieland, E., B. Wehrli, W. Stumm, 1988, The coordination chemistry of weathering: III. A generalization on the dissolution rates of minerals. Geochim. Cosmochim. Acta 52:1969-1981.

Zinder, B., G. Furrer, W. Stumm, 1986, The coordination chemistry of weathering: II. Dissolution of Fe(III) oxides. Geochim. Cosmochim. Acta 50:1861-1869.

Zinder, B., W. Stumm, 1985, Die Auflösung von Eisen(III)-oxiden; ihre Bedeutung im See und im Boden. Chimia 39:280-288.

Zobrist, J., L. Sigg, J. L. Schnoor, W. Stumm, 1987, Buffering mechanisms in acidified alpine lakes. In: H. Barth (ed.), Reversibility of Acidification, Elsevier, Barking, United Kingdom.

Zuo, Y., 1989, Private communication.

Received 29 November 1989. 